\title{
Obtaining Bioethanol through Hydrolytic Treatment of Agro-Industrial Banana Residues
}

\author{
Juan C. Sánchez-Acuña1, Mildred M. Granados-Gómez¹, Luisa F. Navarrete-Rodríguez¹, \\ Jesús G. Rangel-Peraza², Yaneth A. Bustos-Terrones ${ }^{2 *}$ \\ ${ }^{1}$ Grupo de Investigación Tecnoambiental, Facultad de Ingeniería, Universidad Libre, Sede Bosque Popular, Bogotá, Colombia \\ ${ }^{2}$ CONACYT-División de Estudios de Posgrado e Investigación, Instituto Tecnológico de Culiacán, Juan de Dios Batíz 310, Col. \\ Guadalupe, Culiacán, Sinaloa, México \\ Email: *yabustoste@conacyt.mx
}

How to cite this paper: Sánchez-Acuña, J.C., Granados-Gómez, M.M., Navarrete-Rodríguez, L.F., Rangel-Peraza, J.G. and BustosTerrones, Y.A. (2018) Obtaining Bioethanol through Hydrolytic Treatment of Agro-Industrial Banana Residues. Journal of Agricultural Chemistry and Environment, 7, 6072.

https://doi.org/10.4236/jacen.2018.71006

Received: January 19, 2018

Accepted: February 23, 2018

Published: February 26, 2018

Copyright $\odot 2018$ by authors and Scientific Research Publishing Inc. This work is licensed under the Creative Commons Attribution International License (CC BY 4.0).

http://creativecommons.org/licenses/by/4.0/

\begin{abstract}
The banana is a food of great importance and it is consumed in almost the entire world. However, its harvest generates large quantities of mostly lignocellulosic waste, which can be used for the production of biofuels such as bioethanol. In this work, the potential for bioethanol production from agro-industrial plantain crop residues was evaluated with different operating conditions. A $2^{4}$ experimental design was used, having as study variables: time of hydrolysis, $\mathrm{pH}$ of hydrolysis, concentration time, and fermentation time. The samples used were scraps consisting of a mixture of stems, leaves, and banana peels. The bioethanol obtained was characterized by physicochemical properties such as density, refractive index, and FTIR. As a result, it was obtained that the volume of bioethanol represented higher yields; using $\mathrm{NaOH}$ as a hydrolyzing agent, with hydrolysis time of 30 minutes, high fermentation time, and low concentrations. The chemical characterization of banana agro-industrial waste indicated that, the raw material could be considered as a potential source for bioethanol production, since it has a high content of cellulose.
\end{abstract}

\section{Keywords}

Hydrolysis, Lignocellulosic Waste, Banana, Bioethanol, Experimental Design

\section{Introduction}

Banana is one of the most abundant crops in the world, mainly in South America. Each year production increases, as it is part of the daily food of many regions. Currently the banana production worldwide amounts to 145 Million tons per 
year, and it is commercially grown in many varieties in about 120 countries. On the other hand, commercial banana production generates a large proportion of waste. Bello et al. [1] report that for every ton of bananas produced approximately 3 tons of pseudostem, $160 \mathrm{~kg}$ of stems, and $480 \mathrm{~kg}$ of leaves are generated. Thus, an established commercial use for these residues (such as obtaining bioethanol, as well as generating extra remuneration for regional farmers,) would help to reduce environmental pollution which is currently caused by fossil fuels [1]. The burning of these fuels is the main cause of climate change. $\mathrm{CO}_{2}$ emissions from fossil fuel combustion are largely responsible for global warming [2], which is why biofuels appear as an alternative solution, since the percentage of polluting gases emissions they produce is reduced during their production cycle [3]. One solution is the use of biofuels such as Ethanol that is currently used as liquid non-pollutant fuel or as a gasoline enhancer in many countries [4]. Banana waste has the potential to produce ethanol with a low-cost and sustainable production method [1].

Bioethanol serves as a liquid fuel or gas additive in many countries in response to public policy, market pressure, and depletion of the world's energy resources. The production of bioethanol from inexpensive and widely available raw materials is a highly attractive option [4]. Bioethanol is adaptable to 5 or $10 \%$ blended feed systems and it is mainly obtained from biomass, which is competitively given its price, quality and origin [5] [6] [7]. The production of bioethanol based on sugars and starches has been a subject of great controversy due to the food competition that is generated, as well as to the emerge of more sustainable sources from agricultural byproducts, forest residues or energy crops denominated as lignocellulosic biomass or also known as second generation [8] [9]. However, these raw materials present drawbacks due to the high content of lignin and hemicellulose, high cellulose crystallinity and low surface area, so it is necessary to perform a physical, chemical or biological type pretreatment to facilitate the production of biofuel [10] [11].

A large amount of agro-industrial waste generated annually, throughout the world, contains high lignocellulosic levels and starch [12] [13] [14] [15]. Lignocellulose is the main component of biomass, which comprises about half of the plant material produced by photosynthesis and represents the most abundant renewable organic resource in the soil [15]. Since the composition of the lignocellulosic materials depends on various factors [16], it is necessary to adjust certain parameters for each raw material, thus making the structural sugars accessible to the fermentation [15]. One of the most well-known pretreatments is acid hydrolysis, which presents drawbacks such as corrosion of the equipment and the need for neutralization. However, it has a high efficiency in the conversion of hemicellulose to monosaccharides and increases the cellulose digestibility in the solid residues obtained [17]. As for the basic pretreatment, it produces a rupture of the structure of the lignin increasing the internal surface, thus reducing the degree of polymerization and crystallinity [18].

Recent studies about the use of various lignocellulosic residues include fruits 
such as grapes, apples, melons, bananas and, coffee, etc. [19]-[24], to produce bioethanol. In so much as the composition of lignocellulosic materials depends on several factors [16], it is necessary to adapt certain parameters for each raw material, thus making structural sugars accessible to fermentation and obtain bioethanol [15]. One of the most known pretreatments is acid hydrolysis, which has drawbacks such as equipment corrosion and neutralization is needed. However, it has a high efficiency in conversion of hemicellulose into monosaccharides and increases the digestibility of cellulose in the solid waste obtained [17]. As for the basic pretreatment, the degree of polymerization is reduced [18]. In regard to the enzymatic pretreatment, it is a promising topic that is still under development [19] [20], considering that despite reporting high yields of ethanol, it represents high costs due to the adequacy of the systems.

In order to provide added value to banana agro-industrial residues, in this study acid and basic hydrolytic pretreatments were evaluated in order to identify the most appropriate bioethanol production process. The novelty of the present study lies in the use of the design of experiments, particularly solving multiple responses simultaneously. Although the bioethanol obtaining is a topic, which has been extensively studied, hydrolytic treatment of agro-industrial does not frequently use the design of experiments for optimization of their processes. Parts of this work were presented in the event organized by the World Academy of Science, Engineering and Technology and focuses on the optimization of multiple responses in a bioethanol obtaining process [25].

\section{Material and Methods}

The crop waste from banana is generated by management practices in stages such as defoliate, deschante, acorn removal, clearing and dethroning [25]. In this study, the samples used were debris consisting of a mixture of stems, leaves and husks produced by a plantain crop located in the Guayabetal village in the municipality of Yopal, department of Casanare-Colombia.

\subsection{Characterization of the Raw Material}

The most used raw materials for bioethanol production can be classified into three main types: sugars, starches, and cellulose materials [4]. Because banana residues are made up of lignocellulosic fibers, they could be used as raw material for obtaining cellulose or in obtaining bioethanol, in this way, an added value would be provided to say residues.

Initially the raw material was washed with tap water, then dried at $60^{\circ} \mathrm{C}$ for 48 $\mathrm{h}$, and finally mechanical milled using a conventional mill (Corona brand) to obtain a particle size between $1-5 \mathrm{~mm}$. Subsequently, the determination of the percentage of cellulose, hemicellulose and lignin was carried out, in establishing the potential for the raw material in bioethanol production [20].

\subsection{Experimental Design}

The experimental variables evaluated were fermentation time, hydrolysis $\mathrm{pH}$, 
hydrolyzing agent, concentration and hydrolysis time [3] [21]. This work was carried out in duplicate by a $2^{4}$ experimental factorial design, where two levels and four factors were obtained, thus having an arrangement of 16 combinations that are observed in Table 1.

\subsection{Fermentation and Separation}

Initially, a pretreatment to the raw material was carried out, as described in Figure 1 (a). In the fermentation process, the reducing sugars were converted to alcohol using yeast Saccharomyces cervisiae as the fermenting agent, which was activated prior to use (see Figure 1(b)). Finally, the raw material subjected to pretreatment with yeast activated was mixed and kept in an amber bottle in the incubator for 7 or 15 days at a temperature of $25^{\circ} \mathrm{C}$ [22]. The fermented product was manually filtered [23], and fractional distillation was performed according to ASTM method D2892-16.

\subsection{Physical and Chemical Characterization of Ethanol Obtained}

The different bioethanol samples obtained were characterized by the refractive index using a PZO Warszawa Poland refractometer with temperature control of $+/-0.1$, specific gravity $\left(20^{\circ} \mathrm{C}\right)$ and infrared spectrum through a Shimadzu FTIR spectrophotometer, model Prestige-21, following the procedure established in the equipment manual for volatile liquid samples.

\subsection{Statistical Analysis}

In order to evaluate the simple and combined influence of critical variables in the production of bioethanol, a statistical ANOVA factorial analysis was performed using the Statgraphics Plus program, through graphical representation with a Pareto diagram.

\section{Results and Discussion}

\subsection{Characterization of the Raw Material}

The chemical characterization of banana agro-industrial waste (Table 2) indicated that, the raw material can be considered as a potential source for the production of bioethanol as it has a high content of cellulose. When comparing its composition with lignocellulosic materials, studies in the literature find a low percentage of hemicellulose and lignin, which increases the production of reducing sugars, and that the optimal hydrolytic pretreatment could include hydrolyzing agents in relatively low concentrations [3] [6] [24].

\subsection{Density-Concentration-Refractive Index of Bioethanol Obtained}

Figure 2 shows that the density values closest to anhydrous ethanol $(0.789 \mathrm{mg} / \mathrm{L}$ to $20^{\circ} \mathrm{C}$ ) come from samples obtained through basic hydrolytic pretreatment with 30 minutes hydrolysis time. The lignin degradation of the lignocellulosic 
Table 1. Experimental design—study variables.

\begin{tabular}{|c|c|c|c|c|}
\hline Tests & $\begin{array}{c}\text { Reagent } \\
(\mathrm{pH})\end{array}$ & $\begin{array}{c}\text { Concentration } \\
\text { (M) }\end{array}$ & $\begin{array}{c}\text { Fermentation } \\
\text { (Days) }\end{array}$ & Time $(\min )$ \\
\hline 1 & $\mathrm{NaOH}$ & 0.1 & 7 & 30 \\
\hline 2 & $\mathrm{H}_{2} \mathrm{SO}_{4}$ & 0.5 & 7 & 30 \\
\hline 3 & $\mathrm{H}_{2} \mathrm{SO}_{4}$ & 0.1 & 15 & 30 \\
\hline 4 & $\mathrm{NaOH}$ & 0.5 & 7 & 30 \\
\hline 5 & $\mathrm{NaOH}$ & 0.1 & 15 & 30 \\
\hline 6 & $\mathrm{NaOH}$ & 0.5 & 15 & 30 \\
\hline 7 & $\mathrm{H}_{2} \mathrm{SO}_{4}$ & 0.5 & 15 & 30 \\
\hline 8 & $\mathrm{H}_{2} \mathrm{SO}_{4}$ & 0.1 & 7 & 30 \\
\hline 9 & $\mathrm{H}_{2} \mathrm{SO}_{4}$ & 0.1 & 7 & 15 \\
\hline 10 & $\mathrm{H}_{2} \mathrm{SO}_{4}$ & 0.1 & 15 & 15 \\
\hline 11 & $\mathrm{H}_{2} \mathrm{SO}_{4}$ & 0.5 & 7 & 15 \\
\hline 12 & $\mathrm{NaOH}$ & 0.1 & 7 & 15 \\
\hline 13 & $\mathrm{NaOH}$ & 0.1 & 15 & 15 \\
\hline 14 & $\mathrm{NaOH}$ & 0.5 & 7 & 15 \\
\hline 15 & $\mathrm{NaOH}$ & 0.5 & 15 & 15 \\
\hline 16 & $\mathrm{H}_{2} \mathrm{SO}_{4}$ & 0.5 & 15 & 15 \\
\hline
\end{tabular}

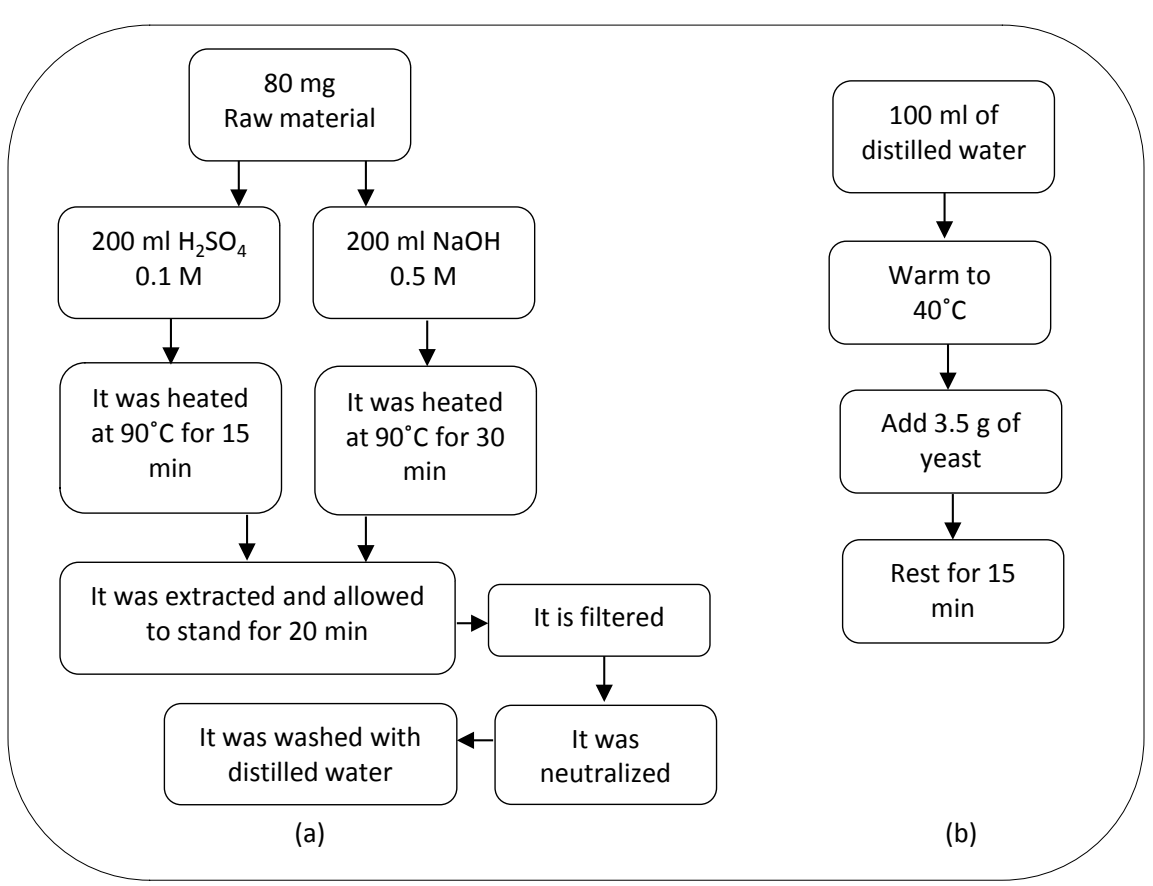

Figure 1. Flow chart for: (a) Chemical pretreatment of organic matter; (b) Activation of the yeast. 
Table 2. Percentage composition of agro-industrial banana residues.

\begin{tabular}{ccc}
\hline Organic fraction & Experimental & Theoretical \\
\hline Lignin (\%) & 11.1 & 12.2 \\
Cellulose (\%) & 50.4 & 28.3 \\
Hemicellulose (\%) & 6.70 & 15.7 \\
\hline
\end{tabular}

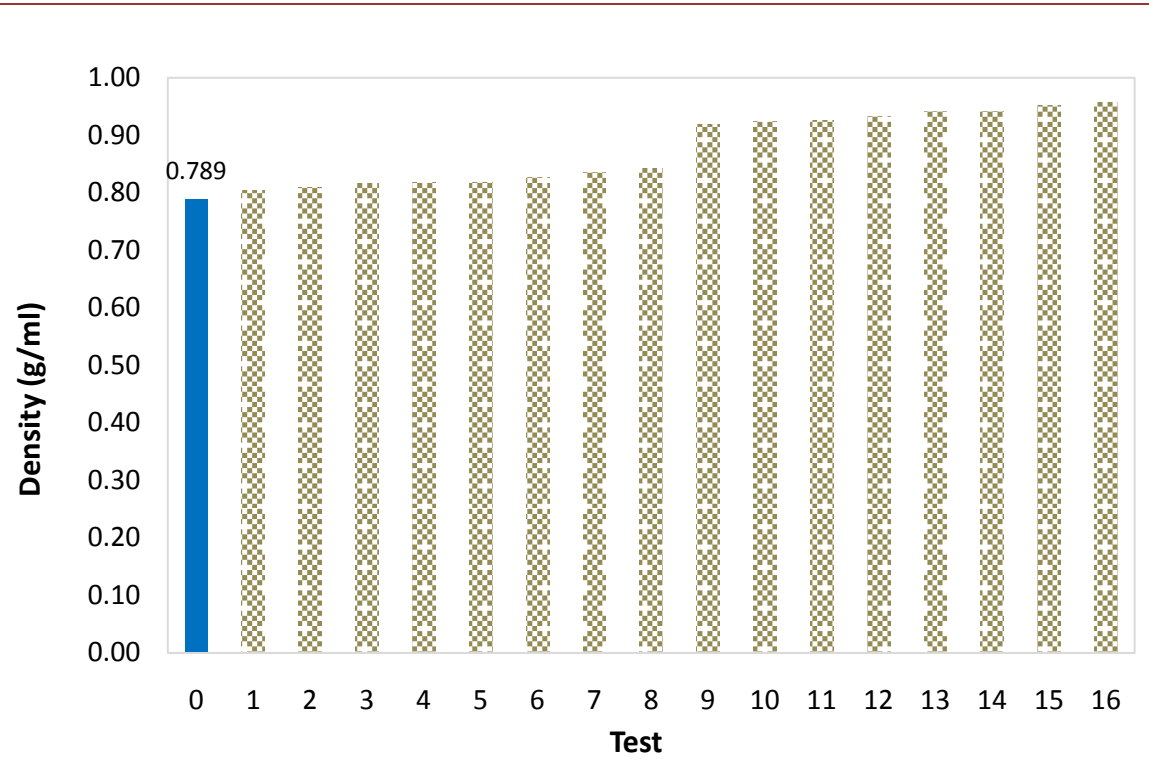

Figure 2. Sample densities of experimental bioethanol.

biomass allows the conversion of cellulose and hemicellulose into simpler sugars more easily digested by the fermentation agent, further decreasing the crystallinity of the cellulose and increasing the surface area [5]. In contrast, the samples obtained with 15 minutes hydrolysis time or acidic hydrolyzing agents represent densities close to the one from water, indicating a composition which water percentage is higher, and therefore, the existence of hydrogen bridges intra and intermolecular [26]. That fact is corroborated when establishing the concentration of bioethanol in each of the samples through the interpolation of the experimental data in theoretical curves of ethanol-water mixtures [27]. Figure 3 shows the increase in the percentage of ethanol as the density of the distillate decreases and approaches the one from pure alcohol.

The refractive index can indicate the purity of a substance or quantify the amount of a component in a binary mixture [28]. Figure 4 shows that the pretreatment with $\mathrm{NaOH}$ showed that the bioethanol had less water, which is reflected in refractive indices closer to the value registered in the literature for ethanol [29].

The experimentally obtained bioalcohol can contain traces of compounds specific to the fermentation process, as well as water, given the characteristic formation of the ethanol-water azeotrope [30] [31]. This bioalcohol cannot be destroyed through separation methods such as fractional distillation. 


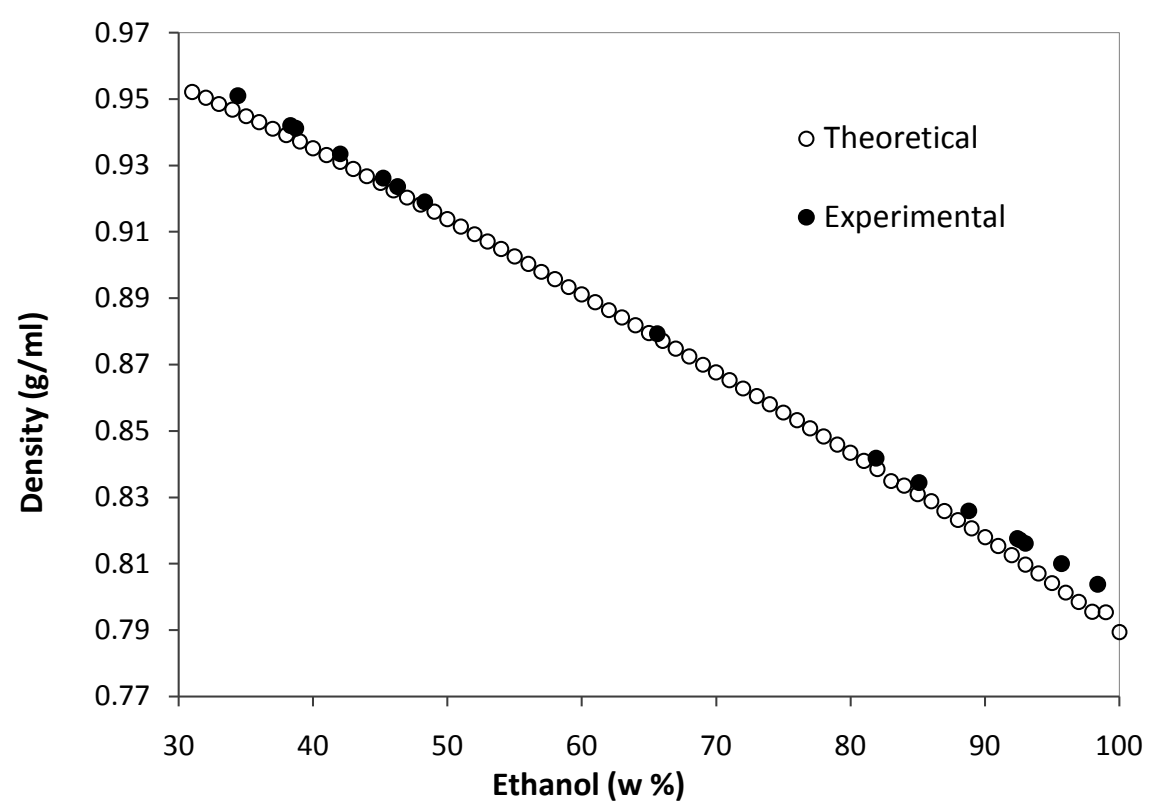

Figure 3. Concentration ethanol-water mixtures.

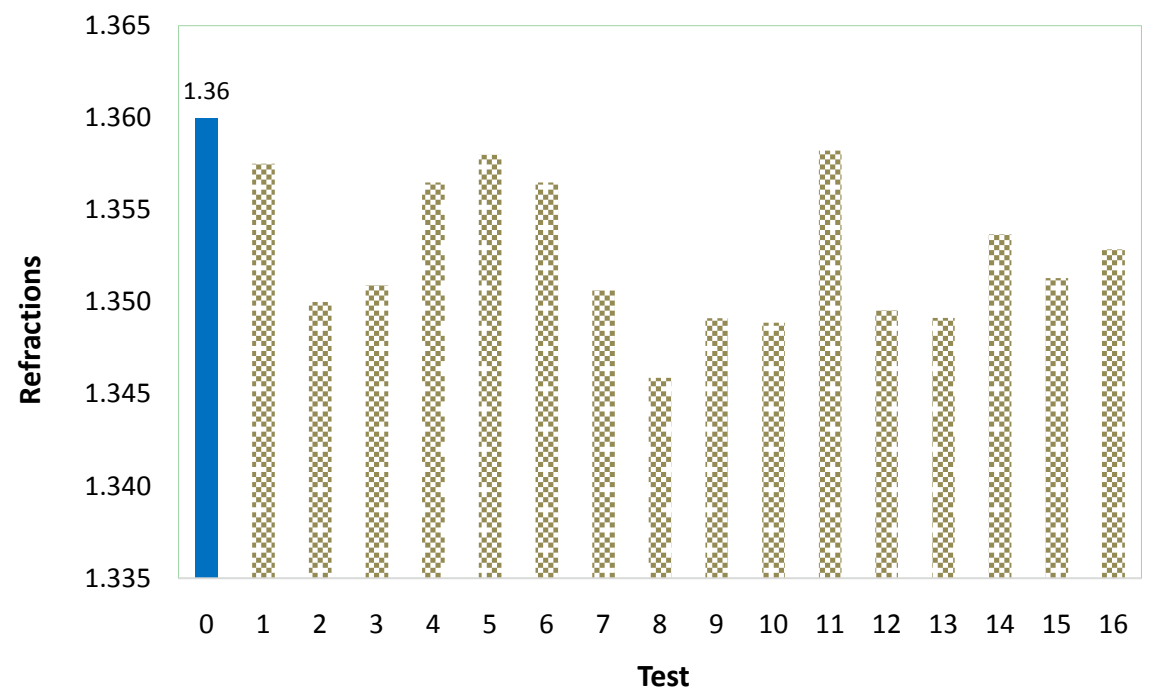

Figure 4. Refractions samples of experimental bioethanol.

Figure 5 shows the differences with respect to the anhydrous compound showing existence of absorption bands, characteristic of the organic alcohol functional group. For the particular case, they correspond to ethanol, and are located between $3050-3600 \mathrm{~cm}^{-1}$ for O-H bond, $2950-3000 \mathrm{~cm}^{-1} \mathrm{C}-\mathrm{H}$ bond and $1000-1100 \mathrm{~cm}^{-1} \mathrm{C}-\mathrm{O}$ bond [32] [33].

\subsection{Statistical Analysis}

The ANOVA statistical analysis showed significant differences between treatments when combinations of $\mathrm{AB}, \mathrm{AD}, \mathrm{BC}$ and $\mathrm{CD}$ variables were performed (Table 3) because the P-Value was higher than the $\lambda$ set at 0.05 . However, it should be mentioned that the individual influence of variables (A, B, C and D) 


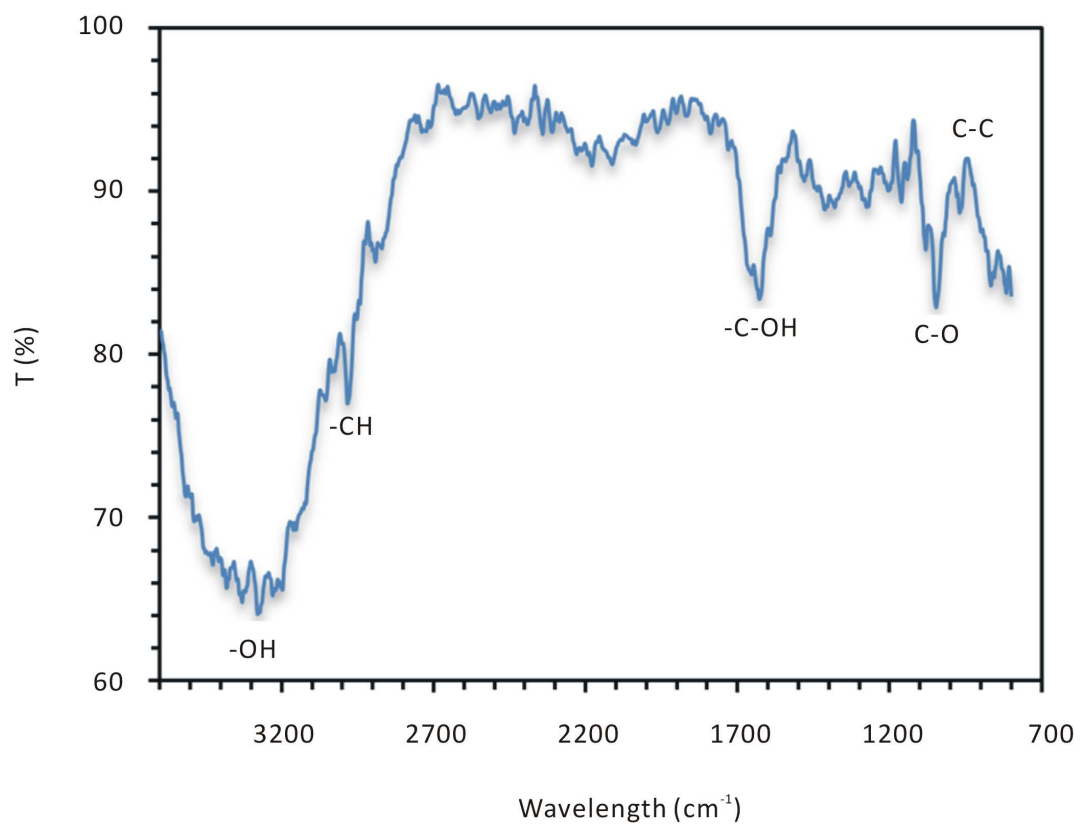

Figure 5. FTIR spectra of bioethanol obtained.

Table 3. Abstract ANOVA treatments bioethanol production.

\begin{tabular}{|c|c|c|c|c|c|}
\hline Source & $\begin{array}{l}\text { Sum of } \\
\text { squares }\end{array}$ & $\begin{array}{l}\text { Degrees of } \\
\text { freedom }\end{array}$ & $\begin{array}{l}\text { Middle } \\
\text { square }\end{array}$ & F-ratio & $\mathrm{P}$-value \\
\hline A: Fermentation time & 8.30281 & 1 & 8.30281 & 11.81 & 0.0026 \\
\hline $\mathrm{B}: \mathrm{pH}$ & 79.1911 & 1 & 79.1911 & 112.67 & 0 \\
\hline C: Concentration & 40.2753 & 1 & 40.2753 & 57.3 & 0 \\
\hline D: Time of hydrolysis & 99.7578 & 1 & 99.7578 & 141.93 & 0 \\
\hline $\mathrm{AB}$ & 0.945313 & 1 & 0.945313 & 1.34 & 0.2596 \\
\hline $\mathrm{AC}$ & 1.55761 & 1 & 1.55761 & 2.22 & 0.1522 \\
\hline $\mathrm{AD}$ & 2.07061 & 1 & 2.07061 & 2.95 & 0.1015 \\
\hline $\mathrm{BC}$ & 0.227813 & 1 & 0.227813 & 0.32 & 0.5755 \\
\hline $\mathrm{BD}$ & 48.2653 & 1 & 48.2653 & 68.67 & 0 \\
\hline $\mathrm{CD}$ & 0.73813 & 1 & 0.73813 & 1.05 & 0.3177 \\
\hline Blocks & 0.01362125 & 1 & 0.01362125 & 0.02 & 0.8907 \\
\hline Total error & 14.0568 & 20 & 0.702842 & & \\
\hline Total & 295.402 & 31 & & & \\
\hline Description & Value & & & & \\
\hline R-Square & 95.2412 & & & & \\
\hline Standard error & 0.838357 & & & & \\
\hline Absolute error & 0.492891 & & & & \\
\hline
\end{tabular}


does not prove to be significant between treatments, which would indicate that these alone would not have a significant influence on the production of bioethanol.

Figure 6 represents the Pareto diagram obtained through the statistical program Statgraphics. The most influential variable in the production of bioethanol is the $\mathrm{pH}$ of hydrolysis, since the best results in general were obtained with a basic pre-treatment $(\mathrm{NaOH})$ because as it was mentioned before, it produces a rupture of the structure of the lignin increasing the internal surface, thus reducing the degree of polymerization and crystallinity [10]. The second most consequential variable was the concentration, as the experimental conditions using a $0.1 \mathrm{M}$ concentration represented a higher yield. At a higher concentration, the cellulose might convert to other molecules that may not be fermentable [22] [34]. The combination of fermentation time and concentration of the hydrolyzing agent showed a greater influence than the independent variable of fermentation time, although this last one proved to have a positive effect, directly proportional to the yield of ethanol. This result could be attributed to the essential role of hydrolysis in the release of cellulose and formation of bioethanol [35].

\subsection{Bioethanol Yield}

Figure 7 shows the yield of bioethanol obtained under different hydrolytic pretreatment conditions. It is seen as a general tendency that $\mathrm{NaOH}$ as a hydrolyzing agent represented better results; tests with hydrolysis time of 30 minutes at basic $\mathrm{pH}(\mathrm{NaOH})$, with high fermentation time and low concentrations tend to have higher yields, the most representative being the test carried out with 15 days of fermentation in a $0.1 \mathrm{M}$ concentration. The aforementioned behavior could be attributed to the fact that hydrolysis at high concentrations may form inhibitory agents that affect the fermentation process, which for the particular case would be present in greater proportion when the $\mathrm{pH}$ of hydrolysis is acidic and for short periods [25]. Although, in the present study the bioethanol obtained is not higher than $35 \%$ in yield, which is low compared with recent researches on banana residues that report ranges from $40 \%$ to $80 \%$ of bioalcohol

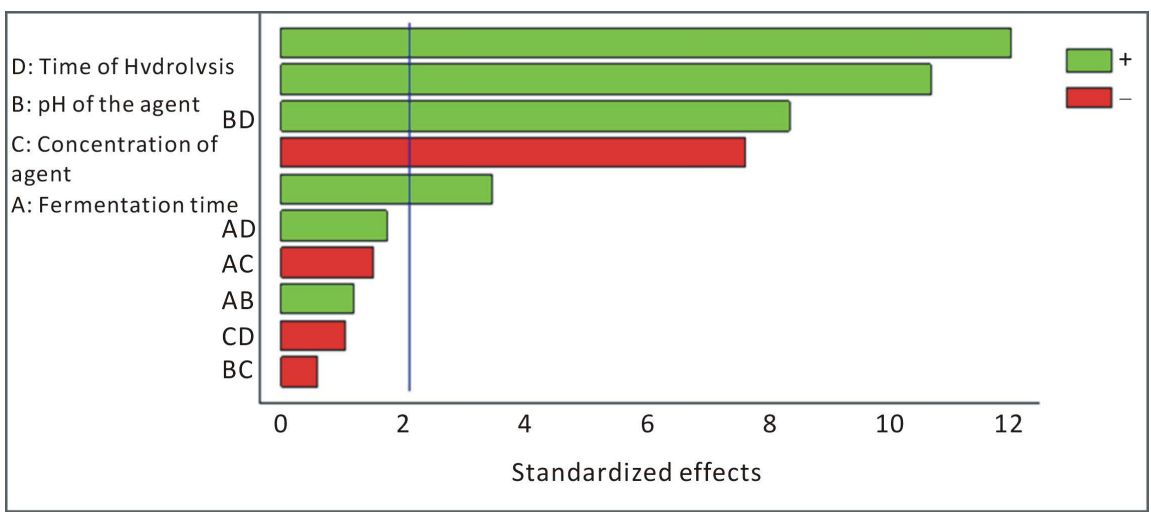

Figure 6. Pareto diagram simple and combined effects $(\mathrm{P}<0.05)$. 


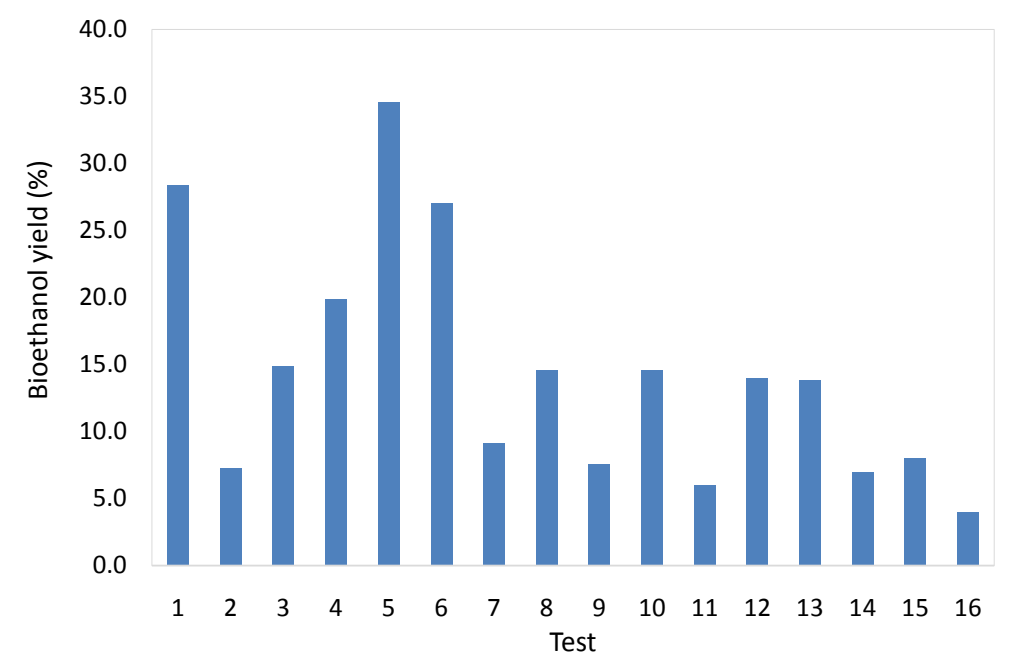

Figure 7. Experimental bioethanol yield under different hydrolysis conditions.

[22] [23] [24]. It is important to take into account that the analysis conditions play a fundamental role since the aforementioned investigations evaluate enzymatic hydrolysis, involving strongly acid pretreatments and high temperatures, while this study was carried out with acid-base hydrolysis, using temperatures and moderate times, which facilitates the use of waste byproducts as part of the solution to the energy demand in remote rural areas and in the development process, giving the population the possibility of using a versatile and much less polluting biofuel [36] [37].

\section{Conclusion}

Banana production is affected by climate change. Nevertheless, these residues can be used to reduce the climate change that affects the production of these same bananas through the production of biofuel such as bioethanol. Benefits in the use of these residues for bioethanol production include the reduction of the environmental impact generated by fossil fuels and the waste of crop residues. Plantain agro-industrial residues represent a raw material with important potential for the production of bioethanol, since they contain a high percentage of cellulose and do not require complex pretreatments to decompose the lignin fraction. In this work, different operating conditions were studied for obtaining bioethanol. A $2^{4}$ experimental design was used, having as study variables: hydrolysis time, $\mathrm{pH}$ of hydrolysis, concentration and fermentation time. It was determined that the most suitable conditions for higher bioalcohol yields correspond to basic pretreatments, 15 days of fermentation and $0.1 \mathrm{M}$ concentration of hydrolyzing agent. The chemical characterization of banana agro-industrial waste indicated that the raw material could be considered as a potential source for bioethanol production.

\section{Competing Interests}

The authors declare that there is no conflict of interests regarding the publica- 
tion of this paper.

\section{Acknowledgements}

The authors thank the Department of Environmental Engineering of the Universidad Libre for providing space, resources and time for researchers, as well as for the support of the "Semilleros de Investigación" program.

\section{References}

[1] Bello, R.H., Linzmeyer, P., Franco, C.M.B., Souza, O., Sellin, N., Medeiros, S.H.W. and Marangoni, C. (2014) Pervaporation of Ethanol Produced from Banana Waste. Waste Management, 34, 1501. https://doi.org/10.1016/j.wasman.2014.04.013

[2] Samsudin, M. and Don, M. (2015) Assessment of Bioethanol Yield by $S$. cerevisiae Grown on Oil Palm Residues: Monte Carlo Simulation and Sensitivity Analysis. Bioresource Technology, 175, 417-423. https://doi.org/10.1016/j.biortech.2014.10.116

[3] Dominguez-Bocanegra, A., Torres-Munoz, J. and Lopez, R. (2015) Production of Bioethanol from Agro-Industrial Wastes. Fuel, 149, 85-89.

https://doi.org/10.1016/j.fuel.2014.09.062

[4] Neagu, C. and Bahrim, G. (2012) Comparative Study of Different Methods of Hydrolysis and Fermentation for Bioethanol Obtaining from Inulin and Inulin Rich Feedstock. Scientific Study \& Research, Chemistry \& Chemical Engineering, Biotechnology, Food Industry, 13, 63.

[5] Zabed, H., Sahu, J., Suely, A., Boyce, A. and Faruq, G. (2017) Bioethanol Production from Renewable Sources: Current Perspectives and Technological Progress. Renewable and Sustainable Energy Reviews, 71, 475-501.

https://doi.org/10.1016/j.rser.2016.12.076

[6] Velásquez-Arredondo, H.I., Ruiz-Colorado, A.A. and De Oliveira, S. (2010) Ethanol Production Process from Banana Fruit and Its Lignocellulosic Residues: Energy Analysis. Energy, 35, 3081-3087. https://doi.org/10.1016/j.energy.2010.03.052

[7] Boluda-Aguilar, M. and Lopez-Gomez, A. (2013) Production of Bioethanol by Fermentation of Lemon Peel Wastes Pretreated with Steam Explosion. Industrial Crops \& Products, 41, 188-197. https://doi.org/10.1016/j.indcrop.2012.04.031

[8] Duque, S., Cardona, C. and Moncada, J. (2015) Techno-Economic and Environmental Analysis of Ethanol Production from 10 Agroindustrial Residues in Colombia. Energy Fuels, 29, 775-783. https://doi.org/10.1021/ef5019274

[9] Damaso, M., Passianoto, M., Freitas, S., Freire, D., Lago, R. and Couri, S. (2008) Utilization of Agroindustrial Residues for Lipase Production by Solid-State Fermentation. Brazilian Journal of Microbiology, 39, 676-681. https://doi.org/10.1590/S1517-83822008000400015

[10] Garcia-Torreiro, M., Lopez-Abelairas, M., Lu-Chau, T. and Lema, J. (2016) Fungal Pretreatment of Agricultural Residues for Bioethanol Production. Industrial Crops and Products, 89, 486-492. https://doi.org/10.1016/j.indcrop.2016.05.036

[11] Gupta, V.K. and Tuohy, M.G. (2013) Biofuel Technologies: Recent Developments. Springer-Verlag, Berlin.

[12] Brar, S.K., Dhillon, G.S. and Soccol, C.R. (2014) Biotransformation of Waste Biomass into High Value Biochemicals. Springer Verlag, New York.

https://doi.org/10.1007/978-1-4614-8005-1 
[13] Nigam, P. and Pandey, A. (2009) Biotechnology for Agro-Industrial Residues Utilisation: Utilisation of Agro-Residues. Springer, Dordrecht. https://doi.org/10.1007/978-1-4020-9942-7

[14] De Almeida, A.F., Dias, K.B., Da Silva, A.C.C., Terrasan, C.R.F., Tauk-Tornisielo, S.M. and Carmona, E.C. (2016) Agroindustrial Wastes as Alternative for Lipase Production by Candida viswanathii under Solid-State Cultivation: Purification, Biochemical Properties, and Its Potential for Poultry Fat Hydrolysis. Enzyme Research, 2016, Article ID 1353497. https://doi.org/10.1155/2016/1353497

[15] Madeira J., Contesini, J., Calzado, F., Ventura, M., Paludetti, M., Branta, D. and Rodrigues, R. (2017) Chapter 18 Agro-Industrial Residues and Microbial Enzymes: An Overview on the Eco-Friendly Bioconversion into High Value-Added Products. Biotechnology of Microbial Enzymes, 475-511. https://doi.org/10.1016/B978-0-12-803725-6.00018-2

[16] Wang, M., Zhou, D., Wang, Y., Wei, S., Yang, W., Kuang, M. and Du, S. (2016) Bioethanol Production from Cotton Stalk: A Comparative Study of Various Pretreatments. Fuel, 184, 527-532.

[17] Fernandes, M.C., Torrado, I., Carvalheiro, F., Dores, V., Guerra, V., Lourenço, P.M.L. and Duarte, L.C. (2016) Bioethanol Production from Extracted Olive Pomace: Dilute Acid Hydrolysis. Bioethanol, 2, 103-111. https://doi.org/10.1515/bioeth-2016-0007

[18] García-Torreiro, M., Pallín, M.Á., López-Abelairas, M., Lu-Chau, T.A. and Lema, J.M. (2016) Alkali Treatment of Fungal Pretreated Wheat Straw for Bioethanol Production. Bioethanol, 2, 32-43. https://doi.org/10.1515/bioeth-2015-0004

[19] Stephen, J. and Periyasamy, B. (2018) Innovative Developments in Biofuels Production from Organic Waste Materials: A Review. Fuel, 214, 623-633.

[20] Mohd-Azhar, S., Abdulla, R., Azmah, S., Marbawi, H., Azlan, J., Azifa, A. and Rodrigues, K. (2017) Yeasts in Sustainable Bioethanol Production: A Review. Biochemistry and Biophysics Reports, 10, 52-61.

[21] Nguyena, Q., Cho, E., Thi Phi, L., Jeon, J. and Hyeun-Jong, B. (2017) Development of an Integrated Process to Produce D-Mannose and Bioethanol from Coffee Residue Waste. Bioresource Technology, 244, 1039-1048.

[22] Gebregergs, A., Gebresemati, M. and Sahu, O. (2016) Industrial Ethanol from Banana Peels for Developing Countries: Response Surface Methodology. Pacific Science Review A: Natural Science and Engineering, 18, 22-29.

[23] Guerrero, A., Ballesteros, I. and Ballesteros, M. (2018) The Potential of Agricultural Banana Waste for Bioethanol Production. Fuel, 213, 176-185.

[24] Guerrero, A. and Muñoz, E. (2018) Life Cycle Assessment of Second Generation Ethanol Derived from Banana Agricultural Waste: Environmental Impacts and Energy Balance. Journal of Cleaner Production, 174, 710-717.

[25] Sánchez, J.C., Granados, M.M. and Navarrete, L.F. (2016) Production of Bioethanol through Hydrolysis of Agro-Industrial Banana Crop Residues. World Academy of Science, Engineering and Technology: International Journal of Biotechnology and Bioengineering, 10, 695-698.

[26] Adekunle, A., Orsat, V. and Raghavan, V. (2016) Lignocellulosic Bioethanol: A Review and Design Conceptualization Study of Production from Cassava Peels. Renewable and Sustainable Energy Reviews, 64, 518-530.

[27] Nadh-Benarji, D. (2016) Statistical Optimizations of Fermentation Factors on Bioethanol Production from Mahua Flower (Madhuca indica) with Saccharomyces ce- 
revisiae by Response Surface Methodology in Batch Bioreactor. Journal of Microbiology and Biomedical Research, 2, 1-7.

[28] Capdevila, V.E., Gely, M.C., Kafarov, V. and Pagano, A.M. (2016) Valorization of Waste Food Industry for Producing Second Generation Bioethanol. Advanced Materials Research, 1139, 33-39. https://doi.org/10.4028/www.scientific.net/AMR.1139.33

[29] Ghosh, S., Chowdhury, R. and Bhattacharya, P. (2017) Sustainability of Cereal Straws for the Fermentative Production of Second Generation Biofuels: A Review of the Efficiency and Economics of Biochemical Pretreatment Processes. Applied Energy, 198, 284-298.

[30] Pérez, O., Díaz, J., Zumalacárregui, L. and Gozá, O. (2010) Evaluación de propiedades físicas de mezclas etanol-agua (II). [Evaluation of Physical Properties of Ethanol-Water Mixtures II.] Revista Facultad de Ingeniería Universidad de Antioquía, 52, 62-74.

[31] Kennes, D., Abubackar, H.N., Diaz, M., Veiga, M.C. and Kennes, C. (2016) Bioethanol Production from Biomass: Carbohydrate vs Syngas Fermentation. Journal of Chemical Technology \& Biotechnology, 91, 304-317. https://doi.org/10.1002/jctb.4842

[32] Green, D. and Perry, R. (2007) Perry's Chemical Engineers' Handbook. 8th Edition, McGraw-Hill, New York, Sec 3-89.

[33] Kaneko, K., Yoshimura, Y. and Shimizu, A. (2018) Water Concentration Dependence of the Refractive Index of Various Ionic Liquid-Water Mixtures. Journal of Molecular Liquids, 250, 283-286.

[34] Mejía, S., Espinal, J. and Mondragón, F. (2006) Estudio del azeótropo Etanol-Agua: Caracterización molecular de dímeros de etanol, heterodímeros y heterotrímeros de Etanol-Agua. [Study of the Azeotrope Ethanol-Water: Molecular Characterization of Ethanoldimers, Heterodimers and Heterotrimers of Ethanol-Water.] Revista Energética, 36, 5-18.

[35] Liebmann, B., Friedl, A. and Varmuza, K. (2010) Applicability of Near-Infrared Spectroscopy for Process Monitoring in Bioethanol Production. Biochemical Engineering Journal, 52, 187-193.

[36] Baena, L., Jaramillo, F. and Calderón, J.A. (2012) Aggressiveness of a 20\% Bioethanol 80\% Gasoline Mixture on Autoparts: II Behavior of Polymeric Materials. Fuel, 95, 312-319.

[37] Nikolić, S., Lazić, V., Veljović, Đ. and Mojović, L. (2017) Production of Bioethanol from Pre-Treated Cotton Fabrics and Waste Cotton Materials. Carbohydrate Polymers, 164, 136-144. 